EarthArXiv Coversheet

$04 / 01 / 2021$

\title{
Hydrated peridotites control the scarcity of water subduction to mid-upper mantle depths
}

Nestor G. Cerpa*

Géosciences Montpellier, University of Montpellier, CNRS, University of Antilles Diane Arcay

Géosciences Montpellier, University of Montpellier, CNRS, University of Antilles José Alberto Padrón-Navarta

Géosciences Montpellier, University of Montpellier, CNRS, University of Antilles Instituto Andaluz de Ciencias de la Tierra, CSIC - University of Granada, Armilla * corresponding author : nestor.cerpa@gm.univ-montp2.fr

This manuscript is non-peer reviewed preprint submitted to EarthArXiv and thus may be periodically revised. The final version will be available via the 'Peerreview Publication DOI' link on the right-hand side of this webpage.

Please feel free to contact the corresponding author; we welcome feedback.

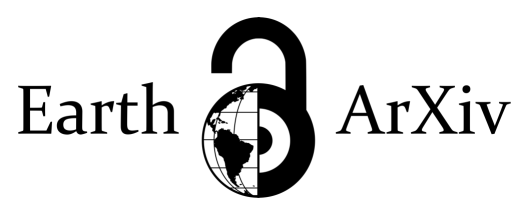




\title{
Hydrated peridotites control the scarcity of water subduction to mid-upper mantle depths
}

\author{
Cerpa N. G. ${ }^{1,2, *}$, Arcay, D. ${ }^{1}$, Padrón-Navarta, J. A. ${ }^{1,3}$ \\ ${ }^{1}$ Géosciences Montpellier, University of Montpellier, CNRS, University of Antilles, 34095 Montpellier \\ Cedex 05, France \\ ${ }^{2}$ Géoazur, University of Côte d'Azur, CNRS, Observatoire de la Côte d'Azur, IRD, 06905 Sophia- \\ Antipolis Cedex, Valbonne, France \\ ${ }^{3}$ Instituto Andaluz de Ciencias de la Tierra, CSIC - University of Granada, Armilla, Granada, Spain \\ * : corresponding author (e-mail : nestor.cerpa@gm.univ-montp2.fr)
}

\begin{abstract}
The presence of liquid water makes our planet unique. Its budget over geological timescales, i.e., the long-term global sea level, depends on the balance of water exchanges between the Earth's mantle and the surface through both volcanism (mantle degassing) and subduction of hydrous minerals (mantle regassing). Current estimates of subduction water fluxes predict that regassing exceeds degassing by $50 \%$, thereby suggesting a sealevel drop of several hundred meters in the last 540 Ma. The models further suggest that the subducting crust is the main supplier of water to the deep mantle. In contrast, various observations advocate for a near-steady state long term sea level and report voluminous water subduction via the hydrated lithospheric mantle. We have revised the subduction water flux calculations using constraints from recent experimental data on natural peridotites under high-pressure and high-temperature conditions. Our novel thermopetrological models show that the present-day global water retention in subducting plates beyond mid-upper mantle depths barely exceeds the estimations of mantle degassing, and thus quantitatively support the steady-state sea level scenario over geological times. Furthermore, the limited mantle regassing is solely driven by the lithospheric mantle of the coldest subduction zones.
\end{abstract}


The water exchange between the Earth's surface and the deep interior is a key process for the evolution of our planet. Water affects the mantle rheology [1] and allows Earth-like plate tectonics [2], while liquid-surface water is essential for planet habitability [3]. The degassing of water from the mantle takes place through volcanism. Mantle regassing occurs via the subduction of water chemically bound to hydrous minerals. Metamorphic reactions with increasing temperature $(\mathrm{T})$ and pressure $(\mathrm{P})$ liberate part of the water from the subducting plates. A fraction of the subducted water is nonetheless retained and returns to the deep mantle. Its proportion remains debated, as does the global cycle of water.

The most comprehensive study on water fluxes at present-day subduction zones estimated a water retention of $3.4 \times 10^{8} \mathrm{Tg} / \mathrm{Myr}$ in oceanic plates beyond a $230-\mathrm{km}$ depth [4]. These thermopetrological models suggested that half of the retention occurred within the oceanic crust, and a third within the hydrated lithospheric mantle, which was assumed to be $2 \mathrm{~km}$ thick worldwide at the trench. Because mantle degassing is approximately $2 \times 10^{8} \mathrm{Tg} / \mathrm{Myr}[5,6]$, the predicted Global Water Retention (GWR) would have induced a drop in the global mean sea level by more than $300 \mathrm{~m}$ over the Phanerozoic (last $540 \mathrm{Myr}$ ) [5], assuming a constant GWR over time. This is, however, close to the upper bound of retention proposed to ensure a modest sea-level decrease during this Eon, thought to be less than $350 \mathrm{~m}$ and more likely approximately $100 \mathrm{~m}$, as inferred from continental-freeboard constraints $[7,8]$.

Furthermore, based on reconstructions of time-dependent subduction rates, it was proposed that GWR was either relatively stable in the past or higher during specific events, e.g., during the rift pulse at approximately $150 \mathrm{Ma}$ [9]. A GWR at present-day of $3.0 \times 10^{8} \mathrm{Tg} / \mathrm{Myr}$ or higher, as predicted by thermopetrological models $[10,4,11,12]$, seems thus inconsistent with a timeintegrated low imbalance between mantle degassing and regassing. Only studies neglecting water subduction via the hydrated mantle were able to reach such a limited mantle regassing [13]. The growing evidence of hydration of the subducted lithospheric mantle exceeding a thickness of $2 \mathrm{~km}[14,15,16]$ urges the need to address this paradox.

The mineralogical changes, with increasing $\mathrm{T}$ and $\mathrm{P}$, during subduction of the mafic crust and of the hydrated ultramafic mantle, control the deep-water fluxes. Hence, quantitative studies of GWR rely on state-of-the-art petrological modeling of hydrated subducted lithologies. 
Lawsonite is the main water carrier in crustal layers beyond subarc depths (Fig. 1a). Its stability field is relatively well known from experimental studies [17,18]. In contrast, the main hydrous phases in peridotitic systems under postarc PT conditions are far less constrained [19]. The large uncertainties partly arise from the difficulty in handling laboratory water-rich experiments with natural samples at mid-upper mantle depth conditions. Hence, experimental data on peridotite are lacking in the 6-8 GPa range (see Supp. Info). Furthermore, the poorly constrained effect of some minor elements (Al, Fe) and the unknown prevailing oxidation state of ultramafic rocks under high-PT conditions [20,21] preclude proper petrological modeling of subducted ultramafic rocks. Consequently, experimental and modeled phase diagrams often differ at pressures above $6 \mathrm{GPa}$ (Fig. $1 \mathrm{~b}$ and 1c).

Here, we update the estimation of present-day GWR by building upon recent experimental results on the stability of hydrous phases in natural hydrated peridotites. By considering the new experimental findings in chemically realistic systems at high PT conditions, the current view of relatively large amounts of water reinjected into the deep upper mantle is challenged.

\section{Thermopetrological modeling of present-day subduction zones}

We model the thermal state of 56 subduction transects [22], representing all present-day subduction zones (see Methods). The thermodynamic database ref. [23] and code Perple_X [24] are used to build phase diagrams, assuming bulk compositions relevant for the crustal and mantle layers at the subduction trenches ("basalt", Fig S3a, "gabbro" and "simple peridotite model" Fig. 1a,b). However, to enhance the accuracy of the modeled mineralogical evolution of hydrated peridotites up to mid-mantle depths, we build a hybrid phase diagram that combines experimentally derived assemblages from naturally complex systems and thermodynamic modeling ("complex peridotite model" Fig. 1c, see Methods).

At shallow depths, water subduction in the basaltic and the gabbroic layers occurs via amphibole, and at subarc and postarc depths via lawsonite [25]. At the depth where the slab surface starts dragging the overlying mantle [26,27], lawsonite is destabilized $\left(700\right.$ to $900^{\circ} \mathrm{C}$ at $8 \mathrm{GPa}$, Fig. 1a) within the basaltic uppermost layers of the subducting plates. Below, the slower heating of the gabbroic layer enables lawsonite to remain stable for most present-day subduction transects up to $\sim 8 \mathrm{GPa}$. At pressures higher than $8 \mathrm{GPa}$, the stability of lawsonite becomes slightly dependent on temperature. Thus, in all but the hottest subduction transects 
(e.g., Cascadia), the oceanic crust crosses its "water line" [28], i.e. the last phase transition beyond which hydrous minerals are unstable, between depths of $250 \mathrm{~km}$ and $310 \mathrm{~km}$.
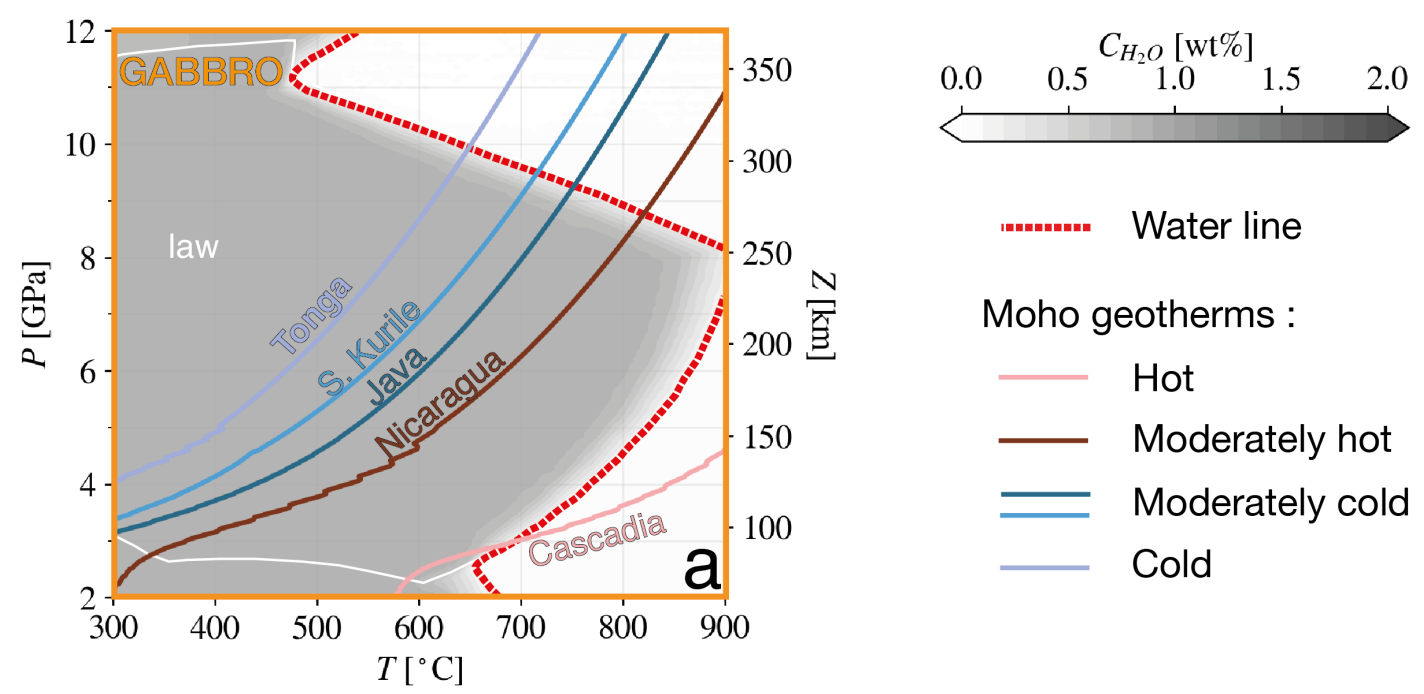

Moho geotherms :
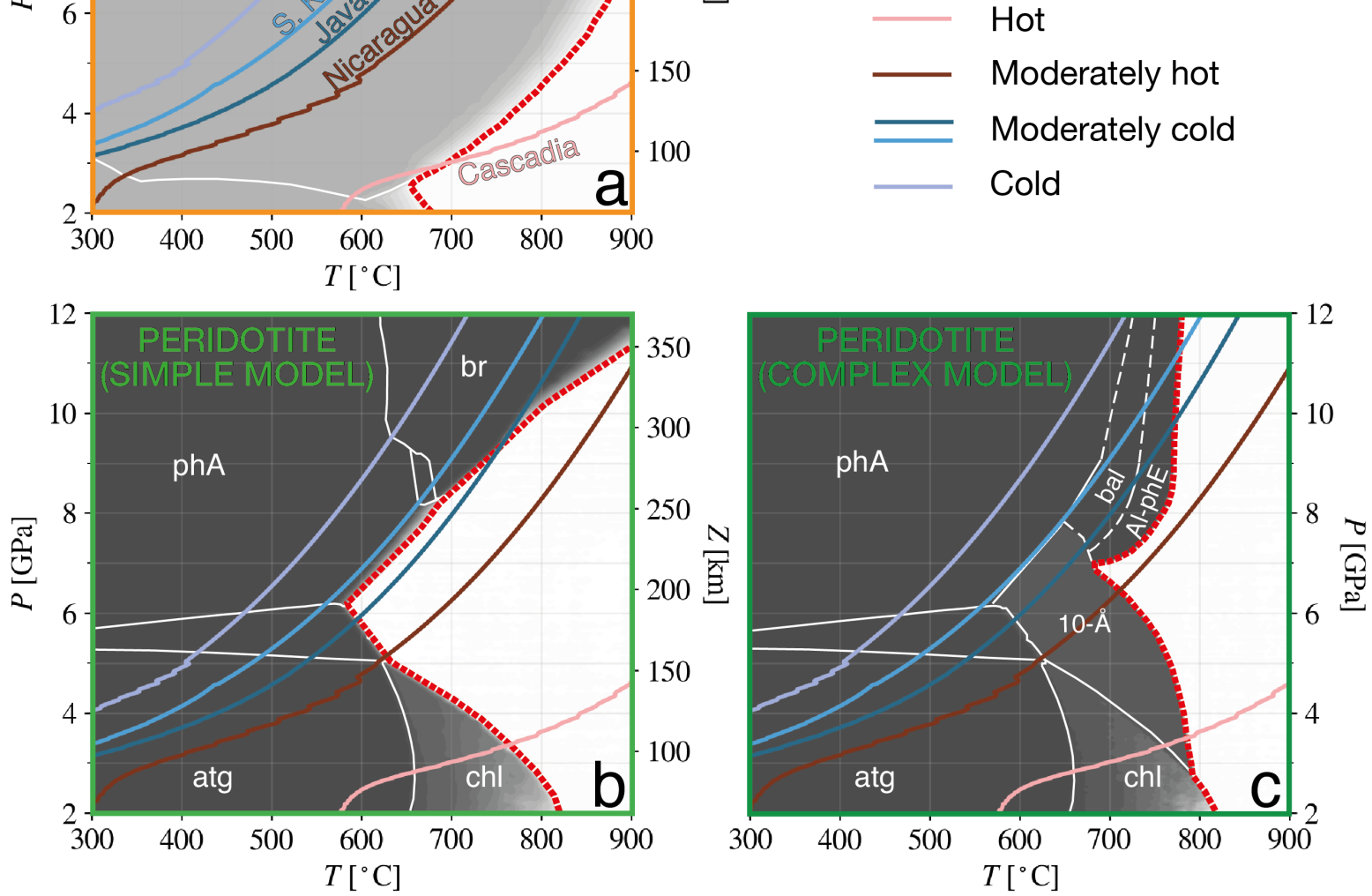

Figure 1: Diagrams of bound-water content for a gabbro (a), a simple peridotite model (b) and a complex peridotite model (c). The stability fields of the main hydrous phases are depicted by white lines. These are lawsonite (law), antigorite (atg), chlorite (chl), phase A (phA), brucite (br), 10- $\AA$ phase (10- $\AA$ ), balangeroite (bal), and aluminous-phase $E$ (Al-phE). For $T$ lower than $600^{\circ} \mathrm{C}$, antigorite and phase $A$ form at pressures lower and higher than 6 $G P a$, respectively, in both peridotite models[17,20]. Chlorite is stable at $T$ and $P$ higher than $600^{\circ} \mathrm{C}$ and lower than $6 \mathrm{GPa}$, respectively. The geotherms at the Moho of selected subduction transects are represented by thick colored lines.

Our two petrological models for peridotite display substantial differences. Below $7 \mathrm{GPa}$, the main difference resides in the formation of the 10 - $\AA$ phase $[29,30,31]$, which enlarges the temperature range of the stability of hydrous minerals in the complex model. The striking 
differences impacting water subduction occur in the mineral assemblages above $8 \mathrm{GPa}$. In the simplified model, phase A breaks down at approximately $650^{\circ} \mathrm{C}$ to form brucite, the stability of which increases with pressure. In contrast, in the complex model, brucite is absent. Balangeroite and aluminous phase $\mathrm{E}$ form instead [20] but within a narrower temperature range compared to that of brucite in the simplified system. These differences in phase assemblages lead to significantly different water lines.

In the thermodynamically (simplified) modeled system, the slope of the water line is negative below $6 \mathrm{GPa}$ and positive above (Fig. 1b). The point of inflection $\left(6 \mathrm{GPa}\right.$ and $\left.580^{\circ} \mathrm{C}\right)$, referred to as the "choke point" [32], controls the water retention in this system. The Moho-geotherms (Tonga, S. Kurile and Java) passing above or near the choke point are quasi-parallel to the water line at higher $\mathrm{P}$, stabilizing hydrous minerals in the lithospheric mantle within a few kilometers below the Moho. The ability of a subducted-mantle geotherm to pass the choke point has thus been related to its capacity to carry water up to mantle-transition depths, where very high-P hydrous phases (E,D) may be stable over a wide range of temperatures $[19,4,33]$.

In the complex peridotite model, the choke point shifts to higher $\mathrm{T}$ and $\mathrm{P}\left(680^{\circ} \mathrm{C}-7 \mathrm{GPa}\right.$, Fig. 1c). This enlarges the range of Moho geotherms stabilizing hydrous minerals beyond 6-7 GPa. However, since the phase transition from aluminous-phase $\mathrm{E}$ to anhydrous olivine is quasiisothermal beyond $8 \mathrm{GPa}$ (ref.), many moderately cold Moho geotherms pass above the choke point but cross the water line between 9 and $12 \mathrm{GPa}$ (see Supp. Info). The combined absence of brucite and the quasi-isothermal water line above $8 \mathrm{GPa}$ become thus potential inhibitors for deep-water subduction.

\section{Near-complete dehydration depths}

To further evaluate the impact of the petrological assumptions, we calculate the depth at which the hydrated lithologic layers nearly become dry (95\% dehydration, see Methods) for all subduction transects, focusing on the lowermost-basaltic, gabbroic and hydrated peridotitic layers (Fig 2). The latter is assumed to be $4-\mathrm{km}$ thick (15\% hydration), which is a reasonable average consistent with geophysical observations [34].

The top basaltic layers mainly dry near the depth at which the slab and mantle are kinematically coupled $(80-110 \mathrm{~km})$. The dehydration of the gabbros occurs within the depth range of 245-295 $\mathrm{km}$ in all but the hottest subduction transects (Fig. 1a). The dehydration pattern of the 
lithospheric mantle is more dependent on the thermal state of the transects. Most importantly, it strongly depends on the petrological model. We thus define three groups based on the way the petrological assumptions impact the mantle-dehydration mode (Fig. 2).

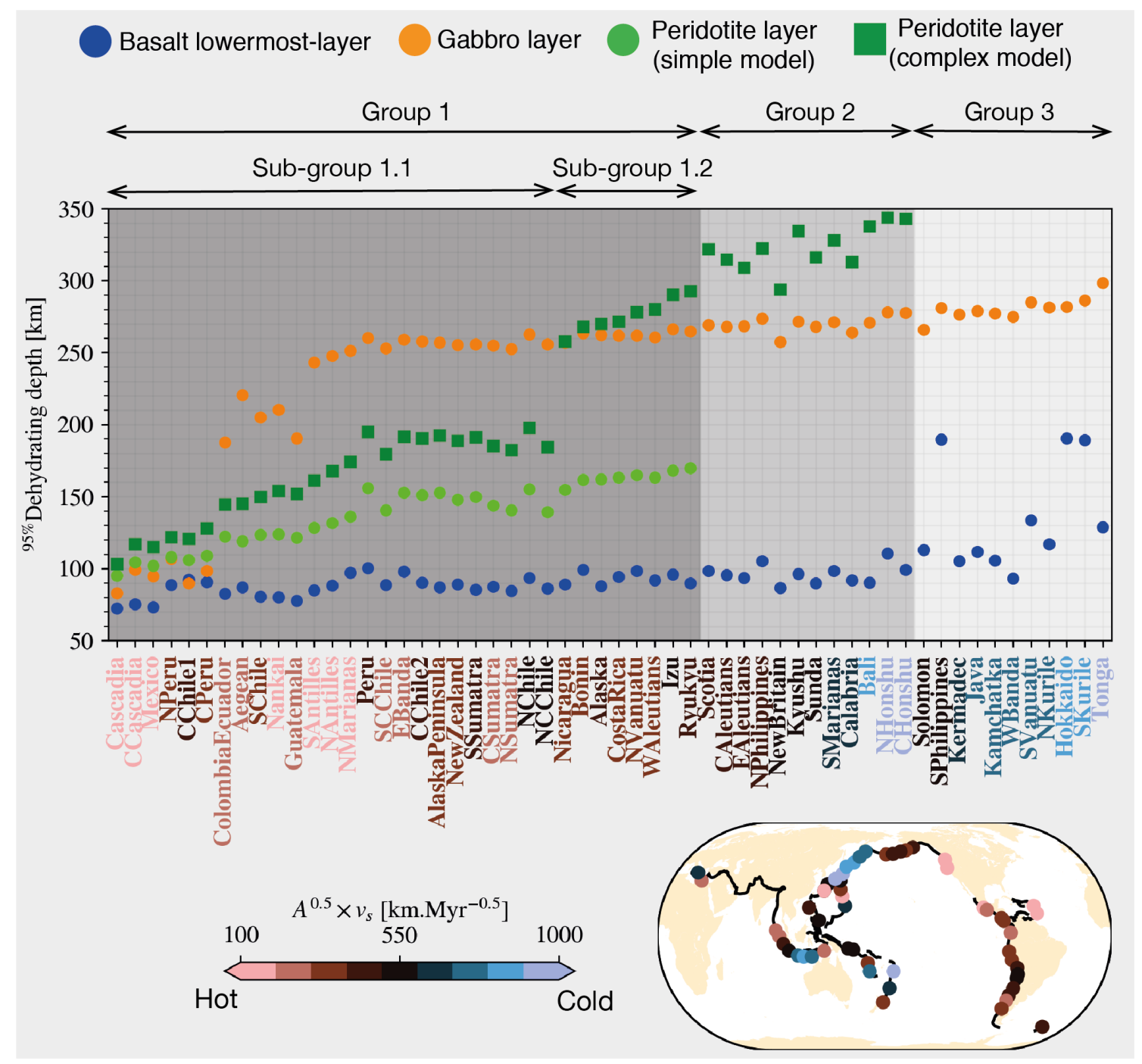

Figure 2: Depth of near-complete (95\%) dehydration of the initially hydrated layers for each subduction transect. The 95\%-dehydration depth of both the synthetic and complex peridotite systems is reported. The subduction transect labels are color-coded following their thermal state, given by the product of the normal convergence rate and the square root of the incoming plate age at the trenches ${ }^{35}$. We define three groups based on the dehydration mode of the hydrated mantle. Group 1: 95\%-dehydration regardless of the phase diagram considered. Group 2: where only with the complex peridotite. Group 3: 95\%-dehydration does not occur in any systems.

Most transects (59\%) belong to group 1, in which the lithospheric mantle mostly dries at depths of $120-170 \mathrm{~km}$, according to the simplified peridotite model. Considering a complex peridotite 
model, the formation of the $10-\AA$ phase in hot and moderately hot transects (subgroup 1.1) deepens lithospheric mantle drying by $10 \mathrm{~km}$ (Cascadia) to $45 \mathrm{~km}$ (NCChile). Apart from the hottest transects, the deepest water subduction in subgroup 1.1 is limited by the breakdown of lawsonite. If the 10- $\AA$ phase breaks down to balangeroite and aluminous-phase E (moderately cold geotherms, subgroup 1.2), dehydration occurs up to $290 \mathrm{~km}$ (Ryukyu), deeper than in the simplified system but does not exceed a 300-km depth (breakdown of aluminous-phase E). The transects of group 2 ( $21 \%$ of the total, moderately cold to cold geotherms) never dry when assuming a simplified peridotite model, owing to the formation of phase A and brucite. In contrast, the complex peridotite model leads the lithospheric mantle to dehydrate between depths of $300 \mathrm{~km}$ and $350 \mathrm{~km}$. The hydrated mantle in the coldest-slab transects, forming the last group (20\% of the total), never dries before reaching the mid-upper mantle (bottom of the modeled domain) in the complex peridotitic model. These coldest transects are thus the only ones able to convey water to the mantle transition zone.

\section{Global water retention}

We now estimate the global water fluxes using the complex peridotite model (Fig. 3). First, our predicted global water input at the trenches is $12.4 \times 10^{8} \mathrm{Tg} / \mathrm{Myr}$ for a 4-km thick hydrated mantle (see Methods), which is consistent with previous estimations, considering the additional $10^{8} \mathrm{Tg} / \mathrm{Myr}$ of water that is carried by sediments [4].

We estimate a global $5.7 \times 10^{8} \mathrm{Tg} / \mathrm{Myr}$ of water retained in subducted slabs at a $230-\mathrm{km}$ depth, just after the mantle dehydration of the subduction zones forming subgroup 1.1. The GWR at a $230-\mathrm{km}$ depth is driven by the initially hydrated mantle (61\%) and by the gabbroic layer (35\%). This value of GWR exceeds the global outgassing $\left(2 \times 10^{8} \mathrm{Tg} / \mathrm{Myr}[5,6]\right)$ and overreaches the upper limit of regassing $\left(3.8 \times 10^{8} \mathrm{Tg} / \mathrm{Myr}\right)$ ensuring a relatively stable sea level during the Phanerozoic [5].

Because gabbros are all dry at a depth of $300 \mathrm{~km}$, the GWR at a $350-\mathrm{km}$ depth is controlled by the lithospheric mantle of cold subduction zones (group 3) and equals $1.3 \times 10^{8} \mathrm{Tg} / \mathrm{Myr}$. By adding the water subducted within sediments $\left(0.3 \times 10^{8} \mathrm{Tg} / \mathrm{Myr}\right.$ at a $230-\mathrm{km}$ depth [vk11] $)$, the revised GWR becomes similar to the estimated global outgassing $\left(2 \times 10^{8} \mathrm{Tg} / \mathrm{Myr}\right)$. Assuming that the GWR has been roughly stable through time [4,9], our results quantitively support a very 
weak imbalance between mantle degassing and regassing, ensuring less than approximately 100 $\mathrm{m}$ of sea level change through the Phanerozoic [5].

Our new thermopetrological model for peridotite suggests that a large amount $\left(4.1 \times 10^{8} \mathrm{Tg} / \mathrm{Myr}\right)$ of water is released between depths of 230 and $350 \mathrm{~km}$, the fate of which would be controlled by the subsequent fluid migration paths. In fact, an underlying assumption for our estimation of GWR is that the released water at these depths ends in the outgassing budget. This is reasonable since recent fluid-flow modeling studies suggest multiple mechanisms for redirecting deep-released water towards the arc [36,37]. A small amount of those fluids may nonetheless be conveyed to the mantle transition zone through hydration of nominally hydrous minerals in the slab $(\sim 0.1 \mathrm{wt} \%$, [38]) but in moderate proportions compared to our estimated GWR.

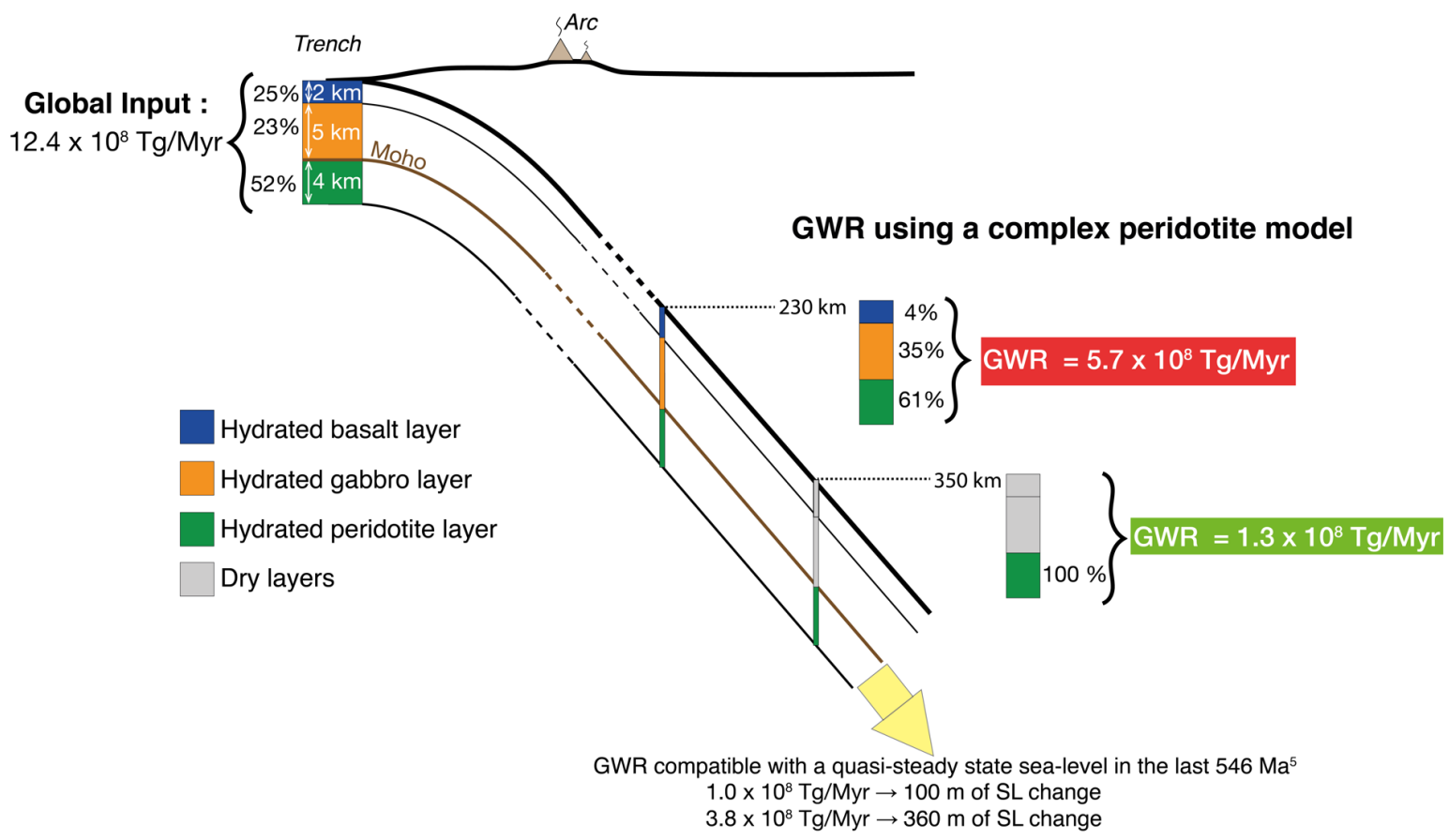

Figure 3: Global water retention in present-day subduction zones computed using a complex peridotite model for the hydrated lithospheric mantle. For comparison, we display the GWR inferred from the bounds on Phanerozoic sea-level changes based on continental freeboard constraints 5 .

In addition to addressing the past inconsistency between previous calculations of GWR by thermopetrological modeling and indirect estimations of mantle regassing, our work further reconciles the former with a range of geophysical observations. Seismic reflection and 
tomography show that the oceanic mantle is hydrated up to depths of 10-30 km below the Moho at various present-day subduction trenches $[39,16,40]$, but extensional earthquakes at the outer rise suggest that hydration mostly occurs within the first $5 \mathrm{~km}$ of the oceanic mantle [15]. Noticeably, we predict that an average serpentinization thickness of 4-6 km below the Moho is consistent with observed long-term mean sea-level variations. Additional calculations with a 6$\mathrm{km}$ and an $8-\mathrm{km}$ thick hydrated mantle at subduction trenches lead to GWRs of $2.6 \times 10^{8} \mathrm{Tg} / \mathrm{Myr}$ and $4.1 \times 10^{8} \mathrm{Tg} / \mathrm{Myr}$, respectively, at a depth of $350 \mathrm{~km}$ (see Supp. Info). Thus, only an 8-kmthick serpentinized mantle may appear excessive regarding the long-term sea level changes. Conversely, a 2-km thick hydrated mantle drops GWR to $0.5 \times 10^{8} \mathrm{Tg} / \mathrm{Myr}$, which would produce an unrealistic sea-level rise over geological times. Too small of an amount of water carried beyond the mid-upper mantle would further be inconsistent with the evidence of hydration of the mantle transition zone [41,42].

The scarcity of volume-change-induced earthquakes in oceanic plates beyond a depth of 300 $\mathrm{km}$ suggests that, on average, few dehydration reactions occur in the deep upper mantle $[43,44]$. In fact, only very cold-slab subduction zones such as Tonga and Kurile display frequent earthquakes between depths of 300 and $500 \mathrm{~km}$ [43]. This observation is consistent with our predictions that the coldest slabs (such as Tonga, Kuriles or Hokkaido) are the sole water carriers beyond mid-upper mantle depths. This latter outcome of our study concurs with the heterogeneous hydration of the mantle transition zone inferred from shear-wave velocity anomalies [45]. 


\section{Methods}

Thermal modeling We consider two-dimensional thermomechanical models in which the kinematics of the subducting slab and of the overriding crust are prescribed while the creeping mantle wedge is dynamic. The mass, momentum and energy conservation equations are solved assuming that mantle flow has reached a steady state [37]. We consider a composite rheology (diffusion and dislocation) for the wedge where the shear viscosity $\eta$ is written as

$$
\frac{1}{\eta}=\left(\frac{1}{\eta_{\text {diff }}}+\frac{1}{\eta_{\text {disl }}}+\frac{1}{\eta_{\max }}\right)
$$

where $\eta_{\max }$ is the maximum viscosity $\left(10^{24} \mathrm{~Pa} \mathrm{~s}\right)$, and $\eta_{\text {diff }}$ and $\eta_{\text {disl }}$ are the viscosities of diffusion and dislocation creep, respectively. They are given by:

$$
\eta_{i}=\left(A_{i} b^{-\alpha_{i}} C_{O H}^{\beta_{i}} \exp \left(\frac{E_{i}}{R T}\right)\right)^{-\frac{1}{\gamma}} \dot{\epsilon}_{I I}^{\left(\frac{1-\gamma}{\gamma}\right)}
$$

where the subscript ${ }_{i}$ denotes either diffusion or dislocation creep, $b$ is the grain size, and $\dot{\epsilon}_{I I}$ is the second invariant of the strain rate. $A, C_{O H}, E$, and $R$ are the preexponential factor, water content, activation energy, and gas constant, respectively. $\alpha, \beta$, and $\gamma$ are the grain-size, watercontent, and stress exponents, respectively. The rheological parameters are set to experimentally determined values for wet olivine [1] (see the values in the supporting information).

The discretized problem with finite elements is solved with the software TerraFERMA [46]. We use an unstructured mesh with element sizes ranging from approximately $1 \mathrm{~km}$ near the tip of the corner flow to $10 \mathrm{~km}$ sufficiently far from the tip where the gradients are smoother.

Thermal-model setup We perform tests for the 56 transects of major subduction zones defined in previous studies [22,4]. Our models consist of a fixed rigid upper crust, a subducting slab with a prescribed velocity, and a dynamic viscous mantle wedge that is coupled with the slab below a 75-km depth [26] (Fig. S1). We adopt a realistic geometry for the top of the subducting slab based on the model Slab 2.0 [47]. For consistency, we consider realistic geometries above a 150-km depth. At higher depths, we extrapolate the slab surface with a constant dip to the bottom of the model domain. The imposed subducting slab velocity v_slab and upper crust thicknesses of each modeled transect are as in ref 22 and ref 4 . The nature (continental vs. oceanic), which defines the boundary condition on the back-arc side as discussed below, and the thickness of the upper plate, as well as the subduction velocity (trench-normal component) 
and slab age, are taken from ref. 22. The slab thermal structure at the trench is computed following the GDH1 plate cooling model [48]. At the bottom of the slab, we impose the mantle potential temperature $T_{m}=1421.5$, as set in previous estimations of GWR. The surface temperature is set to $0^{\circ} \mathrm{C}$. On the back-arc side, up to the mantle inflow-outflow transition depth, we impose either the GDH1 model when the upper plate is oceanic or a one-dimensional conductive model if the upper plate is continental. The latter temperature boundary condition is capped to the mantle potential temperature. A free-stress boundary condition is imposed on the back-arc side.

Petrological modeling We adopt a generic lithologic model for the hydrated top of the oceanic plates entering the trench [33], which consists of a $2-\mathrm{km}$ thick basaltic layer, a $1.5-\mathrm{km}$ thick gabbroic layer, and a 4-km thick serpentinized lithospheric mantle, unless otherwise stated (see Supp. Info for the input bulk composition). The basaltic layer is subdivided into a $0.3-\mathrm{km}$ thick upper volcanic layer, a $0.3-\mathrm{km}$ thick lower volcanic layer, and a $1.4 \mathrm{~km}$ thick dike layer, which differ by their initial water contents of 3.1, 2.6, and $1.8 \mathrm{wt} \%$, respectively. The gabbroic layer and the hydrated lithospheric mantle layer have initial water contents of $0.8 \mathrm{wt} \%$ and $2 \mathrm{wt} \%$, respectively. Note that a water content in the lithospheric mantle of $2 \mathrm{wt} \%$ corresponds to approximately $15 \%$ serpentinization, which is consistent with serpentinization degrees inferred from geophysical observations (see ref. 33). The phase relations are computed with the thermodynamic code Perple_X [24] using the thermodynamic database of ref 23. More details on the thermodynamic calculations are given in Supp. Info. For the complex peridotite model, we combine the phase assemblages predicted by thermodynamic calculations to experimental data on phase relations at high PT obtained from natural serpentinites containing magnetite (see below).

Complex (natural) peridotite modeling We first compile available experimental data on phase assemblages in natural [20] and modeled peridotite systems containing $\mathrm{Fe}^{3+}, \mathrm{Al}, \mathrm{Ca}$ and $\mathrm{Na}[30,31]$ at temperatures higher than $600^{\circ} \mathrm{C}$ and pressures higher than $4 \mathrm{GPa}$ (see Fig. S2a). These reported phase relations serve as a basis for modifying the pseudosections modeled by using Perple_X under these conditions. Given the lack of experimental data in the range of 6.5 to $8 \mathrm{GPa}$, we derive two approximate phase transitions (10- $\AA$ phase to olivine and Al-bearing phase E to olivine) by implementing two approximations at these P-T conditions: a conservative and a high estimate of the extent of the stability field of the hydrous phases (Fig. S2b). Note 
that our calculations of GWR in the main text rely on the high estimate, but we also provide the values obtained with the low estimate in the Supp. Info (Section S3.3). Mass balances are performed to infer the water contents in the modified phase assemblages (Fig. S2b).

Calculation of the water fluxes We adopt the approach of ref W12 to calculate the water distribution in the two-dimensional subduction models. The hydrated portion of the subducting slab is divided into 500-m wide vertical columns. The columns are further subdivided into cells with a height of $100 \mathrm{~m}$. We then calculate the mass of $\mathrm{H}_{2} \mathrm{O}$ retained by each cell given the PT conditions at its center. The total mass of the water contained in each column (or a lithologic layer) is given by a summation of the water content of the cells and converted into a mass flux (in $\mathrm{Tg} / \mathrm{Myr}$ ) by using the horizontal projection of the subduction velocity at the top of the column. Note that, in our approach, the water mass flux (water retention) at a given depth is that of the vertical column for which the top lies at this depth. We do not consider the rehydration of previously dehydrated cells [49]. Our calculation of the water content suffers from minor numerical artifacts that lead to artificial small amounts of water retained in the computing cells, although the PT conditions of dehydration are reached. As a consequence, we choose to compute the $95 \%$ dehydration depth to analyze the dehydration pattern of the hydrated lithologic layers (Fig. 2). Finally, to calculate the GWR, we multiply the retention modeled for each transect by the corresponding length given by ref S10. Note that the $4 \%$ of water retained in the basaltic crust at a $230-\mathrm{km}$ depth is due to both minor numerical artifacts and small amounts of actual water retention during progressive dehydration (Fig. S3a). 


\section{References}

[1] Hirth, G., \& Kohlstedf, D. (2003). Rheology of the upper mantle and the mantle wedge: A view from the experimentalists. Geophysical Monograph-American Geophysical Union, 138, 83-106. doi: 10.1029/138GM06

[2] Regenauer-Lieb, K., Yuen, D. A., \& Branlund, J. (2001). The initiation of subduction: criticality by addition of water?. Science, 294(5542), 578-580. doi :10.1126/science.1063891

[3] Kasting, J. F., \& Catling, D. (2003). Evolution of a habitable planet. Annual Review of Astronomy and Astrophysics, 41(1), 429-463. doi:10.1146/annurev.astro.41.071601.170049

[4] van Keken, P. E., Hacker, B. R., Syracuse, E. M., \& Abers, G. A. (2011). Subduction factory: 4. Depth-dependent flux of $\mathrm{H} 2 \mathrm{O}$ from subducting slabs worldwide. J. of Geophys. Res.: Solid Earth, 116(B1). doi:10.1029/2010JB007922

[5] Parai, R. I. T. A., \& Mukhopadhyay, S. U. J. O. Y. (2012). How large is the subducted water flux? New constraints on mantle regassing rates. Earth and Planet. Sc. Lett., 317, 396-406. doi: 10.1016/j.epsl.2011.11.024

[6] Hirschmann, M. M. (2018). Comparative deep Earth volatile cycles: The case for $\mathrm{C}$ recycling from exosphere/mantle fractionation of major $(\mathrm{H} 2 \mathrm{O}, \mathrm{C}, \mathrm{N})$ volatiles and from $\mathrm{H} 2 \mathrm{O} / \mathrm{Ce}, \mathrm{CO} 2 / \mathrm{Ba}$, and CO2/Nb exosphere ratios. Earth and Planet. Sc. Lett., 502, 262-273. doi:10.1016/j.epsl.2018.08.023

[7] Hallam, A. (1984). Pre-Quaternary sea-level changes. Annual Rev. of Earth and Planet. Sc., 12(1), 205-243. doi:10.1146/annurev.ea.12.050184.001225

[8] Haq, B. U., \& Schutter, S. R. (2008). A chronology of Paleozoic sea-level changes. Science, 322(5898), 64-68. doi:10.1126/science.1161648

[9] Karlsen, K. S., Conrad, C. P., \& Magni, V. (2019). Deep water cycling and sea level change since the breakup of Pangea. Geochem., Geophys., Geosyst., 20(6), 2919-2935. doi: 10.1029/2019GC008232

[10] Rüpke, L. H., Morgan, J. P., Hort, M., \& Connolly, J. A. (2004). Serpentine and the subduction zone water cycle. Earth and Planet. Sc. Lett., 223(1-2), 17-34. doi: 10.1016/j.epsl.2004.04.018.

[11] Faccenda, M., Gerya, T. V., \& Burlini, L. (2009). Deep slab hydration induced by bending-related variations in tectonic pressure. Nature Geoscience, 2(11), 790-793. doi: 10.1038/ngeo656

[12] Magni, V., Bouilhol, P., \& van Hunen, J. (2014). Deep water recycling through time. Geochem., Geophys., Geosyst., 15(11), 4203-4216. doi: 10.1002/2014GC005525

[13] Wallace, P. J. (2005). Volatiles in subduction zone magmas: concentrations and fluxes based on melt inclusion and volcanic gas data. J. of volcanology and Geothermal Res., 140(1-3), 217-240. Doi: 10.1016/j.jvolgeores.2004.07.023

[14] Contreras-Reyes, E., Grevemeyer, I., Flueh, E. R., \& Reichert, C. (2008). Upper lithospheric structure of the subduction zone offshore of southern Arauco peninsula, Chile, at $\sim 38^{\circ} \mathrm{S}$. J. of Geophys. Res.: Solid Earth, 113(B7). doi:10.1029/2007JB005569

[15] Emry, E. L., \& Wiens, D. A. (2015). Incoming plate faulting in the Northern and Western Pacific and implications for subduction zone water budgets. Earth and Planet. Sc. Lett., 414, 176-186. doi: 10.1016/j.epsl.2014.12.042

[16] Cai, C., Wiens, D. A., Shen, W., \& Eimer, M. (2018). Water input into the Mariana subduction zone estimated from ocean-bottom seismic data. Nature, 563(7731), 389-392. doi:10.1038/s41586-0180655-4

[17] Schmidt, M. W., \& Poli, S. (1998). Experimentally based water budgets for dehydrating slabs and consequences for arc magma generation. Earth and Planet. Sc. Lett., 163(1-4), 361-379. doi: $10.1016 / \mathrm{S} 0012-821 \times(98) 00142-3$

[18] Okamoto, K., \& Maruyama, S. (1999). The high-pressure synthesis of lawsonite in the MORB+ H2O system. American Mineralogist, 84(3), 362-373. doi:10.2138/am-1999-0320

[19] Iwamori, H. (2004). Phase relations of peridotites under H2O-saturated conditions and ability of subducting plates for transportation of $\mathrm{H} 2 \mathrm{O}$. Earth and Planet. Sc. Lett., 227(1-2), 57-71. doi : 10.1016/j.epsl.2004.08.013

[20] Maurice, J., et al. (2018). The stability of hydrous phases beyond antigorite breakdown for a magnetite-bearing natural serpentinite between 6.5 and $11 \mathrm{GPa}$. Contributions to Mineralogy and Petrology, 173(10), 86. doi : 10.1007/s00410-018-1507-9

[21] Maurice, J., et al. (2020). The intrinsic nature of antigorite breakdown at 3 GPa: Experimental constraints on redox conditions of serpentinite dehydration in subduction zones. Contributions to Mineralogy and Petrology, 175(10), 1-23. doi: 10.1007/s00410-020-01731-y.

[22] Syracuse, E. M., van Keken, P. E., \& Abers, G. A. (2010). The global range of subduction zone thermal models. Phys. Earth Planet. Inter., 183(1-2), 73-90. doi : 10.1016/j.pepi.2010.02.004 
[23] Holland, T. J. B., \& Powell, R. (2011). An improved and extended internally consistent thermodynamic dataset for phases of petrological interest, involving a new equation of state for solids. J. of Metamorphic Geology, 29(3), 333-383. doi :10.1111/j.1525-1314.2010.00923.x

[24] Connolly, J. A. D. (2009). The geodynamic equation of state: what and how. Geochem., Geophys., Geosyst., 10(10). Doi:10.1029/2009GC002540

[25] Schmidt, M., \& Poli, S. (2013). Devolatilization during subduction. doi:10.1016/B978-0-08-0959757.00321-1

[26] Wada, I., \& Wang, K. (2009). Common depth of slab-mantle decoupling: Reconciling diversity and uniformity of subduction zones. Geochem., Geophys., Geosyst., 10(10). doi :10.1029/2009GC002570

[27] Arcay, D. (2012). Dynamics of interplate domain in subduction zones: influence of rheological parameters and subducting plate age. Solid Earth, 3(2), 467-488. doi:10.1016/j.epsl.2006.12.027

[28] Liu, L. G. (1987). Effects of $\mathrm{H} 2 \mathrm{O}$ on the phase behaviour of the forsterite-enstatite system at high pressures and temperatures and implications for the Earth. Phys. Earth Planet. Inter., 49(1-2), 142167. doi:10.1016/0031-9201(87)90138-5

[29] Ulmer, P., \& Trommsdorff, V. (1995). Serpentine stability to mantle depths and subduction-related magmatism. Science, 268(5212), 858-861. doi :10.1126/science.268.5212.858

[30] Fumagalli, P., \& Poli, S. (2005). Experimentally determined phase relations in hydrous peridotites to $6.5 \mathrm{GPa}$ and their consequences on the dynamics of subduction zones. J. of Petrology, 46(3), 555-578. doi:10.1093/petrology/egh088

[31] Dvir, O., Pettke, T., Fumagalli, P., \& Kessel, R. (2011). Fluids in the peridotite-water system up to $6 \mathrm{GPa}$ and $800 \mathrm{C}$ : new experimental constrains on dehydration reactions. Contrib. to Mineralogy and Petrology, 161(6), 829-844. doi:10.1007/s00410-010-0567-2

[32] Kawamoto, T., Hervig, R. L., \& Holloway, J. R. (1996). Experimental evidence for a hydrous transition zone in the early Earth's mantle. Earth and Planet. Sc. Lett., 142(3-4), 587-592. doi : 10.1016/0012-821X(96)00113-6

[33] Komabayashi, T., \& Omori, S. (2006). Internally consistent thermodynamic data set for dense hydrous magnesium silicates up to $35 \mathrm{GPa}, 1600 \mathrm{C}$ : implications for water circulation in the Earth's deep mantle. Phys. Earth Planet. Inter., 156(1-2), 89-107. Doi: 10.1016/j.pepi.2006.02.002

[34] Hacker, B. R. (2008). H2O subduction beyond arcs. Geochem., Geophys., Geosyst., 9(3). doi:10.1029/2007GC001707

[35] Maunder, B., van Hunen, J., Bouilhol, P., \& Magni, V. (2019). Modeling slab temperature: A reevaluation of the thermal parameter. Geochem., Geophys., Geosyst., 20(2), 673-687. doi: 10.1029/2018GC007641

[36] Wilson, C. R., Spiegelman, M., van Keken, P. E., \& Hacker, B. R. (2014). Fluid flow in subduction zones: The role of solid rheology and compaction pressure. Earth and Planet. Sc. Lett., 401, 261274. doi :10.1016/j.epsl.2014.05.052

[37] Cerpa, N. G., Wada, I., \& Wilson, C. R. (2017). Fluid migration in the mantle wedge: Influence of mineral grain size and mantle compaction. J. of Geophys. Res.: Solid Earth, 122(8), 6247-6268. doi:10.1002/2017JB014046

[38] Padrón-Navarta, J. A., \& Hermann, J. (2017). A subsolidus olivine water solubility equation for the Earth's upper mantle. J. of Geophys. Res.: Solid Earth, 122(12), 9862-9880. doi: 10.1002/2017JB014510

[39] Naif, S., Key, K., Constable, S., \& Evans, R. L. (2015). Water-rich bending faults at the Middle America Trench. Geochem., Geophys., Geosyst., 16(8), 2582-2597. doi:10.1002/2015GC005927

[40] Herath, P., et al. (2020). Hydration of the crust and upper mantle of the Hikurangi Plateau as it subducts at the southern Hikurangi margin. Earth and Planet. Sc. Lett., 541, 116271. doi:10.1016/j.epsl.2020.116271

[41] Huang, X., Xu, Y., \& Karato, S. I. (2005). Water content in the transition zone from electrical conductivity of wadsleyite and ringwoodite. Nature, 434(7034), 746-749. doi:10.1038/nature03426

[42] Pearson, D. G., et al. (2014). Hydrous mantle transition zone indicated by ringwoodite included within diamond. Nature, 507(7491), 221-224. doi : 10.1038/nature13080

[43] Omori, S., Komabayashi, T., \& Maruyama, S. (2004). Dehydration and earthquakes in the subducting slab: empirical link in intermediate and deep seismic zones. Phys. Earth Planet. Inter., 146(1-2), 297-311. doi : 10.1016/j.pepi.2003.08.014

[44] Green II, H. W., Chen, W. P., \& Brudzinski, M. R. (2010). Seismic evidence of negligible water carried below 400-km depth in subducting lithosphere. Nature, 467(7317), 828-831. doi:10.1038/nature09401 
[45] Houser, C. (2016). Global seismic data reveal little water in the mantle transition zone. Earth and Planet. Sc. Lett., 448, 94-101. doi:10.1016/j.epsl.2016.04.018

[46] Wilson, C. R., Spiegelman, M., \& van Keken, P. E. (2017). Terra FERMA: The Transparent Finite Element Rapid Model Assembler for multiphysics problems in Earth sciences. Geochem., Geophys., Geosyst., 18(2), 769-810. doi :10.1002/2016GC006702

[47] Hayes, G. P., et al. (2018). Slab2, a comprehensive subduction zone geometry model. Science, 362(6410), 58-61. doi: $10.1126 /$ science.aat4723

[48] Stein, C. A., \& Stein, S. (1992). A model for the global variation in oceanic depth and heat flow with lithospheric age. Nature, 359(6391), 123-129. doi:10.1038/359123a0

[49] Wada, I., Behn, M. D., \& Shaw, A. M. (2012). Effects of heterogeneous hydration in the incoming plate, slab rehydration, and mantle wedge hydration on slab-derived $\mathrm{H} 2 \mathrm{O}$ flux in subduction zones. Earth and Planet. Sc. Lett., 353, 60-71. doi :10.1016/j.epsl.2012.07.025

Code availability The code TerraFERMA used to compute the thermal models is open-source and available here http://terraferma.github.io/. The thermodynamic code Perple_X is freely available here http://www.perplex.ethz.ch/and information to reproduce the results are provided in the Supp. Info.

Acknowledgments The authors would like to thank Andrea Tommasi and Serge Lallemand for their very useful suggestions, and Stéphane Arnal and Fabien Rétif for their assistance in installing the code on the clusters. This study was publicly funded by through ANR under the "Investissements d'avenir, Initiative Sciences Innovation Territoires-MUSE" program with the reference ANR-16-IDEX-0006. The work has been realized with the support of the HPC Platform MESO@LR, financed by the Occitanie / Pyrénées-Méditerranée Region, Montpellier Mediterranean Metropole and the University of Montpellier.

Author contributions N. C. conceived the study, performed the numerical models and the analysis of the results, and wrote the first draft of the paper. D. A. provided funding for the project and contributed to the analysis of the results. J. A. P.-N. performed the petrological modeling and contributed to the analysis of the results. All authors discussed the implications of the study and participated to the writing of the paper. 